\title{
Fizyk jako element aksjosfery czasów Związku Radzieckiego (na przykładzie reportaży Hanny Krall i Jacka Hugo-Badera)
}

\author{
The physicist as an element of the axiosphere \\ of the Soviet Union's times (based on the reportages \\ by Hanna Krall and Jacek Hugo-Bader)
}

\begin{abstract}
The article attempts to analyse the conceptualisation of the scientist-physicist based on the examples of selected reportages by Hanna Krall and Jacek Hugo-Bader. The analysis was conducted in an axiolinguistic key and its aim was to confirm the thesis about the important role of physicists in the Soviet axiosphere. It can be observed that in the axiological profile of a physicist, obtained on the basis of an empirical analysis, instrumental values dominate and these are closely connected with the fact that physicists are associated with political interests. Physicists, who function as objects of evaluation in the analysed reportages, are also a means of an indirect evaluation in relation to the political system in the USSR and reflect ways in which the country treats its citizens. The empirical material analysed allows us to conclude that within the Russian linguistic-cultural area, the physicist does not refer us only to a scientist dealing with a specific research discipline, but deserves to be called a concept that reflects a characteristic stage of the social and political life of the USSR, permanently inscribed into the axiosphere of that period.
\end{abstract}

Keywords: axiosphere, conceptualization, physicist, values, Soviet Union

Daria Słupianek-Tajnert, Uniwersytet im. Adama Mickiewicza w Poznaniu, Poznań - Polska, daria. slupianek@amu.edu.pl, ORCID ID: https://orcid.org/0000-0002-4339-1852

Stan konfrontacji między dwoma blokami polityczno-militarnymi, które zarysowały się po II wojnie światowej z USA i ZSRR na czele, określany mianem zimnej wojny, charakteryzował się rywalizacją na wielu płaszczyznach - politycznej, gospodarczej i kulturalnej, jednak kluczowy dla obu stron był w tym okresie wyścig zbrojeń i dążenie obu mocarstw do uzyskania przewagi pod względem posiadanej broni atomowej.

Data oficjalnego rozpoczęcia radzieckiego programu budowania broni jądrowej to 11 lutego 1943 roku. Państwowy Komitet Obrony ZSRR zdecydował 
wówczas o utworzeniu tzw. Laboratorium nr 2, w którym pracami badawczo-rozwojowymi nad energią nuklearną miał kierować Igor Kurczatow (Radziecki program nuklearny, źródło elektroniczne). Działania te nabrały szczególnego rozmachu po zrzuceniu przez Amerykanów bomb atomowych na Hiroszimę i Nagasaki (6 i 9 sierpnia 1945 roku). Spowodowało to natychmiastową reakcję władz Związku Radzieckiego, które przyłączyły się do bezprecedensowego międzymocarstwowego wyścigu po broń jądrową. Józef Stalin 20 sierpnia 1945 roku powołał do życia Komitet Specjalny przy Państwowym Komitecie Obrony ZSRR. W sygnowanym przez niego dokumencie stwierdzającym powołanie Komitetu Specjalnego (Postanovlenie GOKO nr 9887ss/op „O Special'nom komitete pri GOKO”, źródło elektroniczne) znalazły się szczegółowe zadania wyodrębnionego organu, a priorytetem miało być prowadzenie prac ukierunkowanych na jak najszybsze zaprojektowanie i budowę bomby atomowej.

Początki zimnej wojny to również druga fala powstawania w ZSRR specjalnych miast naukowych (pierwsza fala przypadła na lata 30 . XX wieku, kiedy to powstały np. Korolow - określany jako kosmiczna stolica Rosji, Żukowski ośrodek naukowo-badawczy lotnictwa czy Friazino - centrum przemysłu radioelektronicznego). Wyraz naukogrady (ros. наукограды) pojawił się w obiegu naukowym dopiero na początku lat 90 . ubiegłego wieku. Mianem tym określane są miasta bądź ich części charakteryzujące się szczególnie wysoką koncentracją potencjału intelektualnego (naukowców i specjalistów) i naukowo-technicznego, w tym organizacji naukowych, oświatowych, przedsiębiorstw (Lappo, Polân 20-21). Naukogrady odegrały w Związku Radzieckim kluczową rolę w rozwoju wielu dziedzin nauki i gałęzi przemysłu - elektroniki i elektrotechniki, budowy samolotów, przemysłu aerokosmicznego, obronnego, a przede wszystkim - energetyki atomowej. Koncentrując się na ostatniej z wymienionych dziedzin, przywołać należy przede wszystkim miasto Sarow (funkcjonujące wcześniej pod wieloma nazwami, m.in. Kremlow, Arzamas-75, Arzamas-16), w którym od 1946 roku działało centrum jądrowe KB-11, a obecnie znajduje się tam siedziba Rosyjskiego Federalnego Ośrodka Nuklearnego, oraz miasto Dubna - ośrodek, w którym w latach 40. minionego wieku Igor Kurczatow kierował budową akceleratora protonów - aktualnie ma tutaj swoją siedzibę Zjednoczony Instytut Badań Jądrowych.

Powstające $\mathrm{w}$ okresie zimnej wojny naukogrady były ściśle powiązane z przemysłem zbrojeniowym, podejmowane $\mathrm{w}$ nich przedsięwzięcia miały wynieść ZSRR na szczyt rankingu światowego pod względem obronności. Prowadzone badania oraz działalność konstruktorska i wytwórcza odznaczały się różnym stopniem tajności, dlatego naukogrady mogły mieć status miast otwartych lub zamkniętych (ros. 3ATO - закрытое административно-территориальное образование). Te ostatnie pojawiały się w dokumentach pod zaszyfrowanymi na- 
zwami - regularnie zmienianymi i nie figurowały na żadnych mapach. Ich nazwy zostały odtajnione dopiero po upadku Związku Radzieckiego.

Naukogrady były w epoce ZSRR niezwykle uprzywilejowane, mówiono o nich „ulubieńcy państwa” - любимчики государства (Lappo, Polân 241). Opinią taką cieszyły się w szczególności miasta związane z energią jądrową, tzw. atomgrady (ros. атомграды). Palmę pierwszeństwa zyskały one dzięki temu, iż ich wyspecjalizowanie $\mathrm{w}$ dziedzinie fizyki atomowej szło $\mathrm{w}$ parze $\mathrm{z}$ priorytetami rządzących w kwestii uzyskania przewagi militarnej nad przeciwnikiem po drugiej stronie żelaznej kurtyny, a to wpisywało się w obowiązujący kurs propagandowo-ideologiczny.

Podobnie jak można mówić o rankingu naukogradów, tak też można mówić o rankingu zawodów zatrudnionych w nich uczonych. Na jego szczycie uplasowali się pracujący w atomgradach fizycy. Ich zawód zyskał w Związku Radzieckim niewyobrażalny prestiż, wielu z nich $\mathrm{w}$ okresie ZSRR zostało laureatami Nagrody Nobla: w 1958 roku wyróżnienie to otrzymali Paweł Aleksiejewicz Czerenkow, Ilja Michajłowicz Frank i Igor Jewgieniewicz Tamm, w 1962 roku - Lew Dawidowicz Landau, w 1964 roku - Mikołaj Gennadiewicz Basow i Aleksandr Michajłowicz Prochorow, a w 1978 roku - Piotr Leonidowicz Kapica. Fizycy, z uwagi na ówczesną sytuację geopolityczną, nie byli w ZSRR po prostu reprezentantami konkretnej dziedziny nauki, ale jednocześnie - z uwagi na wywieraną na nich często polityczną presję, czynnymi uczestnikami zimnej wojny, zobowiązanymi służyć reżimowi. Wspomnieć można tutaj chociażby o specjalnych więzieniach (ros. щарашка) Ławrientija Berii, szefa NKWD, w których oczekujący na wyroki więźniowie - specjaliści z różnych dziedzin nauki - w zamian za niezsyłanie na Syberię pracowali nad ważnymi dla władz projektami. W ramach systemu szaraszki (swego rodzaju zamkniętego instytutu naukowo-badawczego dla więźniów) pracowali np. Andriej Nikołajewicz Tupolew - konstruktor lotniczy, Siergiej Pawłowicz Korolow - pionier budowy rakiet, Lew Siergiejewicz Termen - fizyk i inżynier, specjalista techniki radiowej (Ings 315-317).

Słowo fizyk stało się jednym ze społeczno-kulturowych znaków epoki radzieckiej. Przykładowo, wskazanie na ten zawód pojawiło się w Związku Radzieckim w nazwie słynnego sporu dwóch kultur - fizyków i liryków, którego określenie zawdzięczamy Borysowi Słuckiemu, autorowi wiersza Fizycy i lirycy (Физики и лирики) rozpoczynającego się słowami: „Dzisiaj fizykom owacje. / Dzisiaj lirycy nie w cenie” („Что-то физики в почете. / Что-то лирики в загоне”). Fizycy i lirycy symbolizują $\mathrm{w}$ wierszu Słuckiego środowiska humanistów i przyrodników, tzw. dwie kultury, o których dyskusję zapoczątkował swym wykładem na Uniwersytecie w Cambridge (w maju 1959 roku) Charles Percy Snow (Szczeklik, źródło elektroniczne). Wiersz Słuckiego był opublikowany w październiku 1959 roku w „Gazecie Literackiej” („Литературная газета”) i odzwierciedlał w swej 
treści rzeczywistą sytuację ówczesnej epoki rozwoju techniki. Jak pisze Maria Pietrowna Ignatowa:

Физики в то время, действительно, были в почете: околоземное пространство бороздили искусственные спутники Земли и первый из них был советским, арктический лед грозно крушил первый в мире атомный ледокол „Ленин”. В подмосковном Обнинске уже работала первая в мире промышленная атомная электростанция, а о могучем джинне, выпущенном физиками, напоминала трагедия Хиросимы и Нагасаки. До полета Юрия Гагарина оставалось менее двух лет (Ignatova 17).

Zaprezentowane tło historyczno-kulturowe podporządkowane jest nadrzędnemu celowi badawczemu, a mianowicie przedstawieniu tekstowej konceptualizacji uczonego fizyka jako istotnego elementu radzieckiej aksjosfery okresu zimnej wojny. Jako materiał egzemplifikacyjny posłużyły cytaty z reportażu Fizycy Hanny Krall oraz Archipelag złotego deszczu Jacka Hugo-Badera. Reportaż Fizycy przynależy do cyklu $\mathrm{Na}$ wschód od Arbatu (Krall), wydanego po raz pierwszy w 1972 roku. Wspomniana seria reportaży to rezultat trzyletniej (1966-1969) pracy Krall w Związku Radzieckim jako korespondentki prasowej tygodnika „Polityka". Z kolei reportaż Hugo-Badera pod tytułem Archipelag złotego deszczu ukazał się na łamach „Gazety Wyborczej” w 2000 roku (Hugo-Bader 2000), a następnie w tomie $W$ rajskiej dolinie wśród zielska (Hugo-Bader 2010), zawierającym teksty będące efektem podróży dziennikarza po uwielbianej przez niego Rosji i krajach byłego Związku Radzieckiego.

Reportaż należy do literatury faktu, definiowany jest jako „gatunek dziennikarsko-literacki, którego podstawową funkcję stanowi sprawozdanie za pośrednictwem obserwatora (reportera) o prawdziwych wydarzeniach, sytuacjach, ludziach" (Gazda, Tynecka-Makowska 634). Wyznaczniki reportażu to m.in. aktualność, autentyzm, akcyjność oraz osobisty stosunek reportera do przedmiotu sprawozdania (Gazda, Tynecka-Makowska 634). Ostatnia z wymienionych cech bezpośrednio aktualizuje aksjologiczny pierwiastek w języku. W kontekście zaprezentowanej definicji słownikowej warto również zwrócić uwagę na cechę referencjalności reportażu, o której pisze w swojej monografii Katarzyna Frukacz:

Zarówno estetyka, jak i epistemologia utworów reportażowych zawiera się w konstytutywnej dla nich kategorii referencjalności, czyli w ich odniesieniu do pozajęzykowej empirii. Doświadczanie i dokumentowanie realności w tekstach prozatorskich - zwłaszcza tych faktograficznych - nadaje im rangę tropów rzeczywistości, których charakter odzwierciedla mniej lub bardziej wiernie bieżącą scenerię społeczno-kulturową (Frukacz 23).

Aby zrealizować cel badawczy, w niniejszym artykule zastosowana została analiza aksjolingwistyczna korespondująca z paradygmatem językoznawstwa kognitywnego. Wybór tego właśnie paradygmatu wydaje się naturalny w kontekście 
niektórych wymienionych cech reportażu. Zarówno aksjologiczny pierwiastek w języku, uwarunkowany osobistym stosunkiem reportera do przedmiotu sprawozdania, jak i wspomniana wyżej cecha referencjalności reportażu przywodzą na myśl słowa Jewgienii Fiodorowny Sieriebriennikowej (aktywnie zajmującej się w swych badaniach naukowych zagadnieniami aksjolingwistyki), podkreślającej ,głęboki wymiar oceniający fundamentalnego paradygmatu ontologicznego «człowiek - język - kultura - świat (światy)»” (Serebrennikova et al. 5). Jako że reportaż nie stroni od ocen, to z punktu widzenia pragmatyki jedną z jego podstawowych funkcji jest właśnie funkcja oceniająca. Poszerzona analiza wyrażanych w języku ocen i wartości, wychodząc poza płaszczyznę langue, otwiera się na każdy z elementów wspomnianego przez Serebrennikową paradygmatu. Wszystkie jego elementy aktualizowane są $\mathrm{w}$ antropocentrycznym podejściu do języka w ramach językoznawstwa kognitywnego.

Nawiązując do wspomnianego wcześniej głównego celu badawczego, argumentuję na rzecz tezy, iż fizyk jest istotnym elementem radzieckiej aksjosfery okresu zimnej wojny, czego postaram się dowieść na przykładzie poświadczeń tekstowych zaczerpniętych z wybranych reportaży Krall i Hugo-Badera. Analiza materiału ma na celu odczytanie, zbudowanie i usystematyzowanie odzwierciedlonej w języku konceptualizacji uczonego ze szczególnym uwzględnieniem czynnika aksjologicznego. Zorientowany na odniesienie do różnych typów wartości językowy obraz fizyka, oparty na danych tekstowych, dla swej pełniejszej charakterystyki często domaga się odniesień do rzeczywistości pozajęzykowejżywego reagowania na cechy momentu historycznego, sytuacji społecznej, politycznej czy kulturowej odpowiedniego okresu dziejowego. W drugim etapie analizy materiału empirycznego podejmuję próbę wyróżnienia - typowych dla każdego z reportażystów z osobna - dominujących środków wyrażających taką, a nie inną konceptualizację aksjologiczną naukowca. Proponowaną analizę można zatem określić jako aksjolingwistyczno-kulturową.

Szeroki wykład dotyczący problematyki wartości w różnych koncepcjach filozoficznych, od starożytności począwszy, znajdziemy w klasycznej dla aksjolingwistyki monografii Jadwigi Puzyniny Język wartości (Puzynina). Opierając się na pracach z zakresu filozofii, autorka prezentuje również własną propozycję typologii wartości. $Z$ uwagi na to, iż analiza będzie zawierała odniesienia do tej właśnie klasyfikacji, referuję pokrótce najważniejsze jej elementy. Punktem wyjścia w zaproponowanym przez Puzyninę podziale jest rozróżnienie wartości instrumentalnych (służebnych) oraz wartości ostatecznych (absolutnych). Te dwie klasy autorka uważa za uniwersalne, zastrzega jednak, że wartości określone mianem ostatecznych nie zawsze i dla każdego takowymi będą - „Są to tylko wartości, które mogą być ostateczne, ale które niejednokrotnie [...] funkcjonują jako instrumentalne" (Puzynina 39). Zarówno wartości instrumentalne, 
jak i ostateczne dzielą się na pozytywne i negatywne (podział z punktu widzenia wartości uznawanych przez X-a). Podstawowymi określeniami leksykalnymi pozytywnych i negatywnych wartości instrumentalnych będą odpowiednio pożyteczny, pożytek, użyteczny (i in.) oraz nieużyteczny, nieużyteczność, nieprzydatny (i in.). Z kolei w ramach wartości pozytywnych ostatecznych Puzynina proponuje podział na wartości 1) transcendentne (metafizyczne), 2) poznawcze, 3) estetyczne, 4) moralne, 5) obyczajowe, 6) witalne, 7) odczuciowe (w tym hedonistyczne). Autorka podaje dla każdej z wymienionych kategorii jądro pojęciowe (np. dla wartości moralnych będzie to dobro drugiego człowieka/ grupy ludzi, dla wartości estetycznych - piękno, dla witalnych - życie). Szczególną uwagę zwraca na charakter wartości odczuciowych, do których zalicza przede wszystkim wartości hedonistyczne, opierające się na dążeniu do szczęścia o różnych postaciach, mogą to być, przykładowo, wartości materialnego posiadania (Puzynina 39-41). W kontekście zaprezentowanej klasyfikacji warto podkreślić, że granice między poszczególnymi typami są rozmyte, a wartości mogą się wzajemnie zazębiać. Ryszard Tokarski zauważa, iż szczególnie często obserwujemy to zjawisko w przypadku wartościowania pośredniego wyrażonego na płaszczyźnie języka, kiedy to opiera się ono na konotacyjnych cechach słowa (Tokarski 149).

Konceptualizacja uczonego fizyka przez pryzmat typów wartości, rysująca się na podstawie analizy wyekscerpowanych z reportaży cytatów, zawiera wspólny dla obojga reportażystów trzon, choć każdy z autorów w odmienny sposób rozmieszcza akcenty. Wartością nadrzędną jest wartość instrumentalna. Wyeksponowanie użyteczności zawodu fizyka zauważamy u Krall: „Wiedzą, że ich praca pozwala zajrzeć do tajemnic jądra atomu, a przy tym jest to praca pewna, stabilna, potrzebna. I będzie potrzebna zawsze. Wiadomo, jaka jest rola fizyki w dzisiejszym świecie. To znaczy - ich rola" (Krall 65).

Użyteczność fizyków utrwalona została również w Archipelagu złotego desz$c z u$, co więcej, Hugo-Bader czyni tę pozytywnie rozumianą użyteczność punktem wyjścia do połączenia jej z instrumentalnym traktowaniem fizyków przez rządzących dla realizacji celów politycznych. Użyteczność fizyków i traktowanie ich w sposób instrumentalny związane są z obowiązującym ówcześnie w Związku Radzieckim kursem ideologicznym władz - dążeniem do uzyskania przewagi w zimnej wojnie pod względem posiadanej broni atomowej. Znajdziemy więc w reportażu takie słowa:

Niektórych fizyków trzeba było wyciągnąć z więzień. O Lwa Landaua, późniejszego noblistę, upomniał się Piotr Kapica, także noblista [...] - Towarzyszu Stalin. On mi jest potrzebny. Tylko on może skroplić hel. Bez niego nie będzie fizyki. - Ty, Beria, słyszałeś! Po-trzeb-ny! Oddaj! Puścili (Hugo-Bader 2010: 349-350). 
Aspekt utylitarności uratował przed represjami nie tylko Landaua, ale również, przykładowo, Lwa Altszulera:

Pewnie, że nie mogli go wysłać na Kołymę, bo już za kilka miesięcy, w październiku 1951 roku, miała być testowana druga radziecka bomba atomowa. [...] - Altszuler wam bardzo potrzebny? - Niezbędny - odpowiedział kierownik naukowy Arzamasu-16. Beria pomilczał chwilę. - No dobra - i odwiesił słuchawkę. Altszuler znowu był uratowany (Hugo-Bader 2010: 365-366).

Zdarzało się, iż użyteczność fizyków doraźnie dominowała nawet nad ksenofobią i antysemityzmem. Hugo-Bader przytacza tutaj słowa wybitnego fizyka atomisty, członka Rosyjskiej Akademii Nauk Borysa Ioffego:

Bardzo się bałem - opowiada akademik. - Taki był los mojego pokolenia... To trwało aż do śmierci Stalina w 1953 roku. Starych uczonych, akademików, nie ruszali, byli im potrzebni, a ludzie potrzebni tracili narodowość, nawet Żydzi (Hugo-Bader 2010: 357).

Reporterska konceptualizacja fizyków poprzez pryzmat wartości instrumentalnych eksponuje zatem jednocześnie silne uwikłanie uczonych w reguły obowiązującego systemu politycznego i zmieniające się nastroje polityczne (choć przedstawiciele tego właśnie zawodu nie byli oczywiście jedynymi, którzy znaleźli się w takiej sytuacji). Potwierdzenie znajdziemy w słowach wspomnianego już wyżej Ioffego:

Akurat w 1949 roku pisałem pracę dyplomową, więc mój profesor Izaak Pomieranczuk powiedział, żebym wybrał sobie jakiś temat objęty tajnością, na przykład dotyczący atomistyki, bo wtedy może mnie nie ruszą. Tak zostałem specjalistą od reaktorów atomowych na ciężką wodę. Produkowałem uran i pluton do bomb (Hugo-Bader 2010: 357).

Kolejnym ważnym elementem w analizowanych reportażach jest odniesienie do wartości witalnych poprzez zaakcentowanie odczuwanego przez naukowców lęku przed różnorodnymi represjami, strachu o swoje bezpieczeństwo, zdrowie, a nawet życie. Bardzo wymowny przykład znajdujemy w reportażu Hugo-Badera, przytaczającego słowa Julija Charitona:

Dopiero w 1994 roku, tuż przed śmiercią, Julij Chariton opowiedział w wywiadzie dla rosyjskiego tygodnika „Argumenty i Fakty”, że już przed eksperymentem jądrowym wiedział o przygotowaniach Berii na wypadek niepowodzenia. Ludowy komisarz spraw wewnętrznych zaplanował stosowne represje, przy czym przyjął bardzo proste i jasne kryteria. Ci, którzy w razie sukcesu mieli dostać tytuł Bohatera Pracy Socjalistycznej - w przypadku klapy mieli być rozstrzelani, kawalerowie Orderu Lenina - dostać 25 lat łagru, laureaci Nagrody Stalinowskiej I klasy - 15 lat, II klasy - 10 lat i tak dalej (Hugo-Bader 2010: 359). 
Cytowany przez Hugo-Badera Ioffe mówi nie tylko o strachu odczuwanym przez siebie, ale też w kontekście wspomnianego już Landaua:

Tylko Lew Landau powiedział: „No, nareszcie umarł [Stalin - D.S.-T.]. Już się go nie boję i nie będę więcej pracował". Przyszły noblista miał na myśli pracę nad bronią jądrową, do której się włączył, by zapewnić sobie bezpieczeństwo. [...] - Wystąpić przeciw, to była pewna śmierć, robił więc tylko to, co do niego należało. Pracował dobrze, uczciwie, akuratnie, ale nie przejawiał inicjatywy (Hugo-Bader 2010: 366-367).

Obecność strachu znajduje poświadczenie tekstowe także u Krall, choć jest on wyrażony w sposób bardzo oględny. Autorka pisze o fizykach: „Nie są lekkomyślni zatem. Unikają efektownych gestów. W ogóle nie dają się wziąć na gesty, zwłaszcza gdy wiedzą, że nie są skuteczne" (Krall 65). Wydźwięk tej wypowiedzi staje się jasny dopiero w szerszym kontekście (w reportażu wspomniano m.in. o wojnie, powojennym głodzie i latach stalinizmu, które utkwiły głęboko w pamięci żyjących ówcześnie ludzi).

$\mathrm{Na}$ oddzielną uwagę zasługuje silne zaakcentowanie aspektu materialnego posiadania, co znajduje odzwierciedlenie w wyszczególnianiu przysługujących fizykom profitów. Fizycy, uznani przez władze za potrzebnych, znajdowali zatrudnienie w naukogradach, w których panowały bardzo dobre warunki bytowe. O fizykach pracujących w Dubnej czytamy: „Budowali nowe synchrofazotrony, odkrywali nowe światy, formułowali nowe teorie. A potem kupowali nowe spodnie i buty na skórze i sprowadzali się do przyzwoitych mieszkań, jakie przystoją ludziom z naukowym cenzusem" (Krall 64). Z kolei Hugo-Bader cytuje żonę Wieniamina Cukiermana - fizyka pracującego w Arzamasie-16:

Tam było jak w sanatorium [...]. Po moskiewskiej biedzie i głodzie po prostu oczom nie wierzyliśmy. Nigdy w życiu nie widzieliśmy takiego bogactwa. Pełne sklepy: warzywa, cytrusy, zagraniczne wędliny, kawior, kawa, koniaki i cukier do woli... Nawet czekolada była. I wszystko za kopiejki, bez kartek. Dostaliśmy umeblowane mieszkanie w domu dla kierownictwa, dwie gosposie, samochód z kierowcą. Zarabialiśmy dziesięć razy więcej niż w Moskwie (Hugo-Bader 2010: 353).

Dodatkowe przywileje przysługiwały tym, którzy osiągnęli wymierny efekt swojej pracy w postaci realizacji stawianych przez rządzących zadań:

Naukowcy przyspieszyli pierwszy eksperyment, by zdążyć przed 70. urodzinami Stalina. Do ostatniej chwili jednak nie było wiadomo, czy próba się powiedzie. 29 sierpnia 1949 roku na poligonie atomowym pod Semipałatyńskiem w Kazachstanie wybucha pierwsza radziecka bomba atomowa. [...] Uczeni zostali obsypani nagrodami. Stosowną uchwałę, przygotowaną przez Berię, podpisał osobiście Józef Stalin. Tytuł i Złotą Gwiazdę Bohatera Pracy Socjalistycznej dostało 14 uczonych z Kurczatowem, Charitonem i Zeldowiczem na czele, a także kilku ludzi z aparatu bezpieczeństwa, rządu i partii (Hugo-Bader 2010: 358-359). 
Oprócz pieniędzy nagradzani otrzymywali dacze i samochody, przywileje rozciągały się także na członków ich najbliższej rodziny. W Archipelagu złotego deszczu mowa, przykładowo, o prawie wyboru dowolnych studiów przez dzieci nagrodzonych fizyków czy też o możliwości bezpłatnego korzystania ze wszystkich środków lokomocji w ZSRR z samolotami włącznie (Hugo-Bader 2010: 359).

Oboje reportażystów charakteryzuje fizyków z punktu widzenia wartości poznawczych, podkreślając ich nieprzeciętne zdolności intelektualne. Hugo-Bader fizyków z Arzamasu-16 nazywa „najtęższymi umysłami kraju”:

Miasto zostało specjalnie zbudowane na potrzeby Instytutu Energii Atomowej Akademii Nauk ZSRR. Nazywa się Arzamas-16, ale ludzie mówią krótko: Obiekt. Ławrientij Beria, ludowy komisarz spraw wewnętrznych, a także człowiek odpowiedzialny za budowę radzieckiej bomby atomowej, zgromadził tu najtęższe umysły kraju (Hugo-Bader 2010: 352).

Fizycy cieszą się ogromną wiarygodnością, wtórując hasłu „Fizycy na przedzie, lirycy w tyle", ich metody badawcze są powszechnie poważane i uznawane za przekonujące, czyli również odnajdujemy tutaj aktualizację wartości poznawczych. Krall przytacza w reportażu historię socjologów i pewnego inżyniera, którzy zmuszeni byli do skorzystania z pomocy fizyka w kwestii doboru metody badania materiału empirycznego i zarekomendowania swoich badań w środowisku naukowym:

- Mówią mi socjologowie: „Słuchaj, Garik, mamy świetny materiał faktograficzny, tylko nie możemy sobie poradzić z opracowaniem". Pytam ich - w czym rzecz, riebiata? Okazuje się, że nie dysponują metodą, więc oczywiście wymyśliłem im metodę. Bardzo interesująco to badanie potem wypadło.

Ten sam fizyk dowiedział się, iż jest w Moskwie inżynier, który uważa, że potrafi leczyć raka, i oczywiście wzbudza w środowisku lekarskim naturalną nieufność. Fizyk uznaje, że musi przekonać różnych profesorów, ministrów i urzędy o słuszności metody inżyniera. Co właśnie czyni. W jakim charakterze? Fizyka, to jasne (Krall 66-67).

Pozostaje jeszcze zauważyć w reporterskiej konceptualizacji fizyków odniesienie do wartości moralnych. Hugo-Bader decyduje się postawić w swoim reportażu pytanie o współwinę i uczestnictwo uczonych we wspieraniu reżimu. W rozmowie reportażysty z Lwem Altszulerem padają słowa:

Dlaczego daliście taką straszną broń Stalinowi? [...] - My tylko uchroniliśmy naszą ojczyznę przed atomową zagładą, a świat przed trzecią wojną. Amerykanie już w 1945 roku mieli broń atomową i uśmiercili ludność cywilną dwóch miast. Mieli plany, by zrzucić bomby na Związek Radziecki. - Nie było takich planów. - U nas w gazetach pisali, że były. Naszym patriotycznym zadaniem było nie dopuścić do tego. Do dziś uważam, że gdybyśmy nie mieli tej broni, oni by nas zbombardowali. - Ja myślę, że wspieral pan zbrodniarzy, którzy nawet pana chcieli 
unicestwić [...]. - Po prostu musieliśmy mieć tę bombę. [...] To był nasz obowiązek. - Tam wokół was, wokół Arzamasu-16, były łagry, tam kosili trawę, żeby ludzie nie mieli czego żreć. Codziennie kolumny szły przez miasto. Wszyscy na nie patrzyliście. - Ale my nie dla Stalina. Nie dla Berii. My dla ojczyzny. Dla Rosji [...] (Hugo-Bader 2010: 368).

Wydźwięk etyczny mają również słowa Zinaidy Matwiejewny, żony fizyka Wieniamina Cukiermana:

- I jeszcze takiemu potworowi daliśmy taką straszną broń. - Żona Wieniamina Cukiermana nie wierzy, że to zrobiła. - To nie mogło ujść bezkarnie. Najpierw Bóg nas ostrzegł. Chciał wziąć Irę. Potem umarł nasz syn. Innych też Bóg ostrzegał. Kurczatow żył sam, bez dzieci, w ogromnym pałacu, który mu postawili na terenie Instytutu w Moskwie. Chariton pochował jedyną córkę, Altszulera Bóg pokarał synem schizofrenikiem (Hugo-Bader 2010: 369-370).

Hugo-Bader nie rości sobie tutaj praw do rozstrzygania poruszonych kwestii etycznych, nie formułuje jednoznacznych sądów, pozwala bohaterom uzasadnić konieczność podejmowanych przez nich działań (np. poprzez wyrażenie przekonania o powinności - obecność modalności deontycznej w zdaniu „Musieliśmy mieć tę bombę” oraz dalsze argumenty: „My dla ojczyzny. Dla Rosji” niwelują negatywny wydźwięk sądu „Ja myślę, że wspierał pan zbrodniarzy”). Reportażysta wskazuje na obecność wątku etycznego. Dążąc do wieloaspektowego zmierzenia się z tematem, sygnalizuje konieczność szerokiego spojrzenia zarówno na uczonych fizyków, jak i na moment historyczny, w którym przyszło im prowadzić swoją działalność naukowo-badawczą.

Zarówno Krall, jak i Hugo-Bader zawarli w profilu aksjologicznym odniesienie przede wszystkim do wartości instrumentalnych, witalnych, materialnych i poznawczych. W tym kontekście wymienione grupy wartości można uznać za wyraźne dominanty. Różny jest jednak udział ilościowy treści skorelowanych z nazwanymi wartościami u obojga autorów. W odróżnieniu od Hugo-Badera Krall nie porusza kwestii etycznych dotyczących współwiny fizyków we wspieraniu reżimu komunistycznego. Obecność tego wątku u Hugo-Badera podyktowana została odleglejszym momentem powstania reportażu (niż analizowany tekst Krall), innymi okolicznościami (przede wszystkim brakiem cenzury), które wpłynęły na możliwości formalne i treściowe reporterskiego spojrzenia na fakty.

Przyjrzyjmy się zatem dominującym w tekstach Krall i Hugo-Badera sposobom wyrażania wartościowania (z uwagi na ograniczoną objętość artykułu nie wszystkie środki mogły zostać wyczerpująco omówione), które w największym stopniu zdecydowały o formie przedstawienia problemu. Istnieje bogata literatura dotycząca sposobów wyrażania ocen i wartościowania w języku (Vol'f; Arutûnova; Puzynina; Chlebda; Serebrennikova et al.). Powszechnie uznany jest podział na środki systemowe (czyli skonwencjonalizowane - są to np. środ- 
ki fleksyjne, leksykalne, składniowe czy słowotwórcze) i tekstowe (fakultatywne, zależne od kontekstu czy też od konotacji wyrażeń, np. metafory, hiperbole, eufemizmy, ironia i in.). Ich charakterystykę znajdziemy w monografii Puzyniny (Puzynina 111).

Na profil aksjologiczny uczonego fizyka, zawarty w tekstach analizowanych reportaży, złożyła się m.in. reporterska kreatywna konceptualizacja oceniająca, w której oceny wyrażone zostały nie tylko za pomocą utrwalonych już w języku środków wartościujących, ale też dzięki twórczemu wykorzystaniu środków językowych, pierwotnie niepełniących funkcji oceniającej, lecz mogących zyskać taki status w szerszym kontekście.

Krall, pisząc reportaże tworzące cykl Na wschód od Arbatu, w związku z obowiązującą w tamtych czasach cenzurą nie zawsze mogła pozwolić sobie na mówienie wprost o podejmowanych kwestiach, szczególnie gdy dotyczyły one Związku Radzieckiego. Jak podkreśla Wiesław Kot: „Krall musiała liczyć się z tym, iż jej reportaże będą odczytywane na tle konwencji propagandowej, wymuszającej relacjonowanie pobytu w ZSRR w trybie entuzjastycznych doniesień z kraju wysoce zaawansowanego w budowie socjalizmu" (Kot 17). W czasach, gdy o Związku Radzieckim, jak zauważa Mariusz Szczygieł we Wstępie do Na wschód od Arbatu, można było pisać albo dobrze, albo wcale, Krall w sposób zawoalowany potrafiła zawrzeć treści nieidące w parze z kursem propagandowym. Samą reporterkę Szczygieł określa w tym kontekście jako przemytniczkę ze Związku Radzieckiego, a jej metodę reporterską jako przemyt (Szczygieł 5). Z kolei Małgorzata Szejnert nazywa to zjawisko myleniem pogoni (Szczygieł 8).

Zanim przejdziemy do wypunktowania dominujących w reportażu Fizycy środków wyrażania wartościowania, warto zwrócić uwagę na zastosowany przez pisarkę chwyt reporterski korespondujący z metodą mylenia pogoni, a mianowicie permanentne akcentowanie wyjątkowości fizyków pod różnymi względami (przede wszystkim przez pryzmat typów wartości wyróżnionych w pierwszej części analizy). Biorąc pod uwagę rzeczywistą ogromną rolę uczonych, którą odgrywali w procesie dynamicznego rozwoju nauki i techniki w ZSRR (szczególnie na gruncie fizyki atomowej), dzięki umiejętnemu wysunięciu tego zjawiska na pierwszy plan, co przykuwa uwagę podczas lektury, autorka mogła jednocześnie przekazać między wierszami krytykę niektórych zjawisk zachodzących w Związku Radzieckim.

1. Spośród dominujących w reportażu Fizycy środków wyrażania wartościowania szczególną uwagę zwraca częste kontrastowanie. Przykładowo, z kontrastowaniem z wykorzystaniem presupozycji mamy do czynienia w następującym fragmencie: „Są ludzie, którzy specjalnie jeżdżą po wsiach i skupują stare ikony, a kiedy podbijają cenę do trzystu rubli i zwykli śmiertelnicy kupować już tego nie są w stanie, zwijają spokojnie worki: - Niczewo, fizyki wozmut" (Krall 66). 
Wyraźnie przeciwstawiając fizyków „zwykłym śmiertelnikom” (a wyrażenie to rodzi konotacje z przeciętnością, szarością), Krall uzyskuje tutaj efekt oceniania uczonych nie tyle w odniesieniu do wartości materialnych, ile w odniesieniu do ich „wyjątkowości” w ogóle, dalekiej od przeciętnego, szarego życia „zwykłych śmiertelników" (Krall 66).

Wyraźne kontrastowanie jest obecne również we fragmencie, w którym fizyków przeciwstawia się z kolei humanistom:

Skoro fizyka może wyjaśnić wiele spraw świata współczesnego, skoro dysponuje przy tym żelazną logiką, w przeciwieństwie do humanistów, którzy czasem nawet mają rację, ale czują to jedynie fibrami duszy swojej i nie umieją tego należycie uzasadnić - powstaje przekonanie o wyjątkowej pozycji fizyka, a nawet jego szczególnej misji (Krall 66).

Takich przykładów znajdziemy w tekście więcej.

2. Wyjątkowość fizyków (przede wszystkim na tle wartości poznawczych), podkreślana w powyższym cytacie, zostaje dodatkowo zintensyfikowana dzięki obecności w bliskim sąsiedztwie wartościujących przymiotników zawierających semy intensyfikujące: „wyjątkowa (pozycja fizyka)”, ,jego szczególna misja”. Wykładnikiem intensyfikacji jest tutaj rzeczownik misja, eksponujący posłannictwo do wypełnienia ważnych, odpowiedzialnych zadań, pozwalający przypisać im status wybrańców. Nagromadzenie w bliskiej odległości (w obrębie zdania lub krótkiego fragmentu tekstu) wielu wyrazów (bądź zwrotów) pozytywnie wartościujących lub rodzących kontekstowe konotacje pozytywne możemy zatem określić jako kolejny, obok kontrastowania, często pojawiający się środek wartościowania fizyków w reportażu Krall. Jako ilustracja mogą posłużyć m.in. następujące przykłady:

Człowiek dokonujący znaczących odkryć i dręczony ważkimi niepokojami (Krall 66).

Powstał więc stereotyp fizyka, który fizykom spodobał się tak bardzo, że sami utrwalają go jak mogą - stylem, sznytem, sposobem bycia (Krall 67).

W hierarchii prestiżu zawodów w ZSRR fizyk jest na szczycie drabiny, w hierarchii pragnień maturzystów zajmuje drugie miejsce, za kosmonautą, przy stole jest ozdobą towarzystwa, nic dziwnego więc, że wokól środowiska fizyków powstała już otoczka kibiców (Krall 67).

3. Z pragmatycznego punktu widzenia, aby potwierdzić w konceptualizacji fizyków oczywistość powszechnego przeświadczenia o ich szczególnej roli w ówczesnej radzieckiej aksjosferze, reportażystka stosuje wyrażenia modalne typu: nic więc dziwnego, to jasne, wiadomo.

4. Mówiąc o językowych środkach wyrażania wartościowania w reportażu Krall, nie sposób pominąć cytowanego już wcześniej fragmentu: 
Pamiętają wojnę, powojenny głód, lata stalinizmu, sens XX Zjazdu... Są dorośli. Są rozważni. Wiedzą, że ich praca pozwala zajrzeć do tajemnic jądra atomu, a przy tym jest to praca pewna, stabilna, potrzebna. I będzie potrzebna zawsze. Wiadomo, jaka jest rola fizyki w dzisiejszym świecie. To znaczy - ich rola. Nie są lekkomyślni zatem. Unikają efektownych gestów. W ogóle nie dają się wziąć na gesty, zwłaszcza gdy wiedzą, że nie są skuteczne (Krall 65).

Mając w pamięci odniesienie do wartości witalnych (zachwianie poczucia bezpieczeństwa, strach o swoje zdrowie, a nawet życie), szczególnie należy podkreślić rozwagę uczonych, wymienioną w powyższym cytacie. Reportażystka celowo kieruje uwagę odbiorcy właśnie na tę cechę, nazywając ją dwukrotnie - przy użyciu przymiotnika rozważny oraz poprzez zastosowanie antonimu z partykułą przeczącą - nie sa lekkomyślni. Przymiotnik rozważny, jak czytamy we Wstępie do cyklu Na wschód od Arbatu,

[...] oznacza w 1967 roku coś więcej niż dla nas w roku 2014. Rozwaga jest dla obywateli radzieckich strategią polityczną i życiową. Człowiek rozważny nie narazi się świadomie na gniew władzy i płynące z niego kary i represje. - W rozwadze chodziło o to - mówi dziś Krall - żeby robić swoje, żeby się nie narazić, żeby się nie ześwinić, żeby przejść suchą nogą, przedryfować. [...] Dziś tamte słowa znaczą o wiele mniej, są bardziej dosłowne (Szczygieł 11).

W analizowanym reportażu przymiotnik rozważny jest środkiem silnie wartościującym nie tylko wobec fizyków, ale również - i może przede wszystkim - wobec reguł dyktowanych obywatelom przez ówczesne radzieckie władze.

W kluczu wartościowania można zatem również rozpatrywać zamykający reportaż obraz: „Fizycy są daleko, w tle. Rano wychodzą do pracy, wracają wieczorem, w mieście ich nie widać. Po ulicach Dubnej spacerują babcie z dziećmi i opaleni brodaci kibice w swoich szykownych ubrankach" (Krall 68).

Nieprzypadkowo pojawiły się w zacytowanym fragmencie synonimy kontekstowe daleko, $w$ tle, którym również przypisujemy tutaj rolę wartościującą. $\mathrm{Z}$ jednej strony Krall nakreśliła w swym reportażu barwną konceptualizację pracujących w Dubnej fizyków - błyskotliwych uczonych pozbawionych trosk materialnych, wykonujących prestiżowy zawód (który może być rozpatrywany nawet w kategoriach szczególnej misji), zwracających na siebie uwagę stylem i sposobem bycia, postrzeganych jako idole $\mathrm{z}$ wiernym gronem kibiców. $Z$ drugiej strony z jakiegoś powodu „fizycy są daleko, w tle”. To na pozór nieistotne sformułowanie odsyła nas do omawianych w pierwszej części analizy wartości instrumentalnych. Nie mamy tutaj jednak do czynienia $\mathrm{z}$ wartościowaniem przydatności pracy uczonych, ale raczej z zaakcentowaniem instrumentalnego ich traktowania przez system polityczny (fizyk jako jednostka jest „daleko, w tle”, a na pierwszy plan wysuwa się traktowanie go jako „narzędzia” do realizacji celów politycznych).

W Archipelagu złotego deszczu uczeni, na których skupia się reportaż, to przede wszystkim fizycy atomiści pracujący w atomgradzie Arzamas-16. Znaj- 
dziemy w reportażu ich eksplicytnie wartościujące określenia typu: „najtęższe umysły kraju” (Hugo-Bader 2010: 352), ,wielcy uczeni” (Hugo-Bader 2010: 357), ,awangarda radzieckiej nauki” (Hugo-Bader 2010: 349). Wszystkie wymienione wyrażenia, intensyfikujące ocenianą właściwość, podkreślające nieprzeciętne zdolności intelektualne fizyków (odwołanie do wartości poznawczych), bazują na pozytywnych konotacjach metaforycznych użyć wyrazów tęgi, wielki, awangarda.

Naukowcy zostali także określeni w reportażu mianem ,elity radzieckiego narodu” (Hugo-Bader 2010: 349). Rzeczownik elita, definiowany jako „grupa ludzi wyróżniająca się lub uprzywilejowana w jakimś środowisku, społeczeństwie ze względu na pewne cechy lub posiadanie dóbr cenionych społecznie” (Dubisz), odsyła nas jednocześnie do innych typów wartości składających się na konceptualizację fizyków. Melioratywne określenie „elita radzieckiego narodu” może odnosić się, oprócz wspomnianych wartości poznawczych, również do wartości materialnych (sowite wynagradzanie uczonych za ich osiągnięcia, określane w tekście mianem ,złotego deszczu”, „bajecznych pieniędzy” czy też do instrumentalnych (zawód nad wyraz potrzebny).

Kluczowym, nadrzędnym chwytem w planie wyrażania ocen w reportażu Archipelag złotego deszczu jest aksjologizacja poprzez deskrypcję, dająca się zaobserwować wówczas, gdy wartościowanie uwarunkowane jest kontekstem i implikowane zostaje przez znaczenie deskryptywne (gdy odbiorca może ocenić opisywaną sytuację, zdarzenie itp. in plus bądź in minus). Hugo-Bader, nie będąc zmuszonym do pisania w sposób zawoalowany, głównym środkiem wyrażania wartościowania czyni zatem, najogólniej rzecz ujmując, operowanie konkretnymi okolicznościami historycznymi. Reportażysta przywołuje wspomnienia z życia fizyków atomistów, wymieniając ich z imienia i nazwiska (np. historia wyciągania z więzienia Landaua poprzez wstawiennictwo Kapicy u Stalina - Hugo-Bader 2010: 349-350), pisze o wydarzeniach ze wskazaniem na osoby, daty i okoliczności, szczegółowo wymienia korzyści materialne, podaje konkretne sumy i przywileje, którymi nagradzani byli fizycy, np. po udanej pierwszej próbie wybuchu radzieckiej bomby atomowej pod Semipałatyńskiem, mówi też o karach, które mogły spotkać uczonych w razie niepowodzenia prób jądrowych (Hugo-Bader 2010: 359), wskazuje zarówno nazwiska fizyków popierających działania władz, jak i dysydentów. Pisze wprost o wciągnięciu fizyków w politykę, o pracy motywowanej strachem o swoje bezpieczeństwo, a nawet życie, bezpośrednio przytacza fakty o działaniach NKWD, kiedy kwestia użyteczności była często czynnikiem decydującym o być lub nie być uczonego (Hugo-Bader 2010: 366). Na tym tle fizycy stają się zatem nie tylko obiektem wartościowania, ale także środkiem wartościowania wobec ówczesnego systemu politycznego i instrumentalnego sposobu traktowania obywateli. 
Funkcję wartościującą w reportażu pełni także operowanie ironią. Przytoczę kilka cytatów:

Mają mu [Stalinowi - D.S.-T.] dać broń atomową, więc dla zachęty dostaną nawet odrobinę intelektualnej autonomii (Hugo-Bader 2010: 349).

Niewiarygodne! Z prywatnego telefonu dodzwonili się do Ameryki! [sytuacja dotyczy niedostępnego w ZSRR lekarstwa - streptomycyny, załatwionej dla umierającej córki W. A. Cukiermana w zamian za to, że będzie on pracować przy budowaniu bomb atomowych. Gdy fizyk stawał się potrzebny, „wszystko było możliwe”] (Hugo-Bader 2010: 351).

Ironicznie został również użyty rzeczownik $r a j$ w poniższym cytacie:

Powinienem był milczeć, a nie wytrzymałem i powiedziałem im, że nie we wszystkim się zgadzam z linią partii - mówi Lew Altszuler. - Boże, co się narobiło! / - Myślał pan, że jak się trafi do tego raju, to można wszystko? / - No tak. Mając trzydzieści osiem lat, powinienem mieć więcej oleju w głowie, a ja po prostu nie wytrzymałem. [...] Dlatego chociaż ja jeden musiałem im powiedzieć, że się nie zgadzam! (Hugo-Bader 2010: 363).

Interesujące z punktu widzenia środków wyrażania wartościowania są zaskakujące określenia Arzamasu-16 jako „ogromnego luksusowego obozu pracy” (Hugo-Bader 2010: 353), „ojczystych zarośli” czy „,zony” (Hugo-Bader 2010: 365). W świetle tych sformułowań uczeni mogą zostać określeni mianem elitarnych zeków - żyjących co prawda w bardzo dobrych warunkach, ale jednak w izolacji i uzależnieniu od decydentów. Wymienione wyrażenia aktualizują w profilu aksjologicznym fizyków odpowiednio: odniesienie do wartości materialnych, do wartości instrumentalnych i witalnych. Jak wynika z powyższych informacji, to, co u Krall mogliśmy odczytać tylko między wierszami, w Archipelagu złotego deszczu zostało wyartykułowane wprost.

Analizowane reportaże powstały w odmiennych warunkach społeczno-politycznych, co w naturalny sposób odcisnęło piętno na świadomości twórczej i warsztacie ich autorów - Krall zmuszona była, przykładowo, poradzić sobie z ówczesną peerelowską cenzurą, a reportaż Hugo-Badera powstał już w postsowieckiej rzeczywistości. Niemniej jednak zawarta w reportażach konceptualizacja radzieckiego fizyka otrzymała szeroką, niewykluczającą się, lecz dopełniającą charakterystykę. Chociaż w analizie uwzględnione zostały tylko dwa teksty, to jednak ich przynależność do literatury faktu pozwala wysnuć wnioski dotyczące nie tylko tekstowej konceptualizacji naukowców, ale też, wychodząc poza ramy reportaży - odnieść sformułowane wnioski do szeroko rozumianego rosyjskiego obszaru lingwokulturowego. Poświadczenia tekstowe utrwalają konceptualizację uczonego fizyka z silnie zaznaczoną obecnością pierwiastka aksjologicznego i pozwalają na konstatację, iż w ramach rosyjskiego obszaru lingwokulturowego czasów Związku Radzieckiego 
fizyk nie odsyła nas wyłącznie do naukowca zajmującego się określoną dyscypliną, ale zasługuje na miano konceptu odzwierciedlającego ważny moment życia społeczno-politycznego ZSRR, na stałe wpisując się w ramy aksjosfery tamtego okresu.

Potwierdzenie tych słów znajdujemy także w rosyjskim słowniku asocjacyjnym (Karaulov et al.), w którym zaznaczony został zarówno wysoki status fizyków w hierarchii uczonych, jak i asocjacje współgrające bezpośrednio z zaprezentowanym na wstępie tłem historyczno-kulturowym. Przywołajmy wybrane informacje $\mathrm{z}$ artykułów hasłowych dwóch słów-bodźców - физик (fizyk) oraz ученый (uczony). $\mathrm{W}$ artykule hasłowym dla bodźca физик pojawiło wiele asocjacji odpowiadających konceptowi fizyka utrwalonemu w analizowanych reportażach. Takimi istotnymi z punktu widzenia niniejszego opracowania słowami-reakcjami są bez wątpienia: ученый, теоретик, умный, ядерщик, атом, Курчатов, лаборатория, лирик (Karaulov et al. 701). Interesujący jest również fakt, iż w artykule hasłowym innego słowa-bodźca - ученый pierwszą reakcją nazywającą bezpośrednio przedstawiciela określonej dziedziny nauki jest nie kto inny, jak właśnie физик (Karaulov et al. 697).

Nakreślona w reportażach konceptualizacja fizyków jest dwojaka - z jednej strony jawią się oni jako predestynowani do wyższych celów wybrańcy, osoby wyjątkowe pod względem intelektu, prestiżu i nieodzowności wykonywanej pracy. Charakterystyka ta koresponduje ze spostrzeżeniami Galiny Pietrowny Sidorowej, która, podejmując w swym artykule problematykę wartości zawodów w kulturze czasów ZSRR, pisze o uczonych w dobie rewolucji naukowo-technicznej (ros. HTP - научно-техническая революиия) następująco:

В контексте превращения науки в ведущую силу производства, советские ученые - бескорыстные, самоотверженные трудяги и романтики, которые работают не за страх, а за совесть, кого клещами не оторвешь от любимого занятия, испещряющие математическими формулами салфетки в столовых (Sidorova, źródło elektroniczne).

Z drugiej strony w reportażach Krall i Hugo-Badera znajdziemy poświadczenia tekstowe utrwalające konceptualizację fizyków jako osób zdanych na łaskę lub niełaskę władz, odczuwających strach przed reżimem, ale czasem też i reżim wspierających.

W profilu aksjologicznym fizyka, rysującym się na podstawie analizy materiału empirycznego, dominują wartości instrumentalne i ścisłe ich połączenie z polem gry interesów politycznych. Fizycy, będąc obiektem wartościowania w analizowanych reportażach, są również pośrednio środkiem wartościowania w stosunku do panującego w ZSRR ustroju i zasad jego obchodzenia się z obywatelami. Reportaże Fizycy i Archipelag złotego deszczu, utrwalając postaci fizyków atomistów jako ważny element radzieckiej aksjosfery, pozwalają polskiemu odbiorcy dostrzec odmienne nasycenie konotacyjne konceptu fizyk (przede wszyst- 
kim na płaszczyźnie aksjologicznej), na co wpłynęły realia epoki. Wyraz fizyk ma zatem etnokulturową specyfikę i w płaszczyźnie konotacyjnej jest odbiciem scenerii społeczno-kulturowej czasów Związku Radzieckiego.

\section{Bibliografia}

Arutûnova, Nina Davidovna. Tipy âzykovyh značenij: Ocenka. Sobytie. Fakt. Moskva, Nauka, 1988. Chlebda, Wojciech. „O tekstowych wykładnikach wartościowania”. Przegląd Humanistyczny, 1, 2007, s. 25-34.

Dubisz, Stanisław, red. Uniwersalny słownik języka polskiego [edycja CD-ROM, wersja 1.0]. Wydawnictwo Naukowe PWN, 2004.

Frukacz, Katarzyna. Polski reportaż książkowy. Przemiany i adaptacje. Katowice, Wydawnictwo Uniwersytetu Śląskiego, 2019.

Gazda, Grzegorz, Słowinia Tynecka-Makowska, red. Słownik rodzajów i gatunków literackich. Kraków, Towarzystwo Autorów i Wydawców Prac Naukowych Universitas, 2006.

Hugo-Bader, Jacek. „Archipelag złotego deszczu”. „Magazyn”, 11. Gazeta Wyborcza, 64, 16.03.2000. Hugo-Bader, Jacek. W rajskiej dolinie wśród zielska. Wołowiec, Wydawnictwo Czarne, 2010.

Ignatova, Mariâ Petrovna. „«Fiziki» i «liriki»: dve kul'tury včera i segodnâ”. Izvestiâ Saratovskogo universiteta. Novaâ seriâ. Seriâ.: Filosofiâ. Psihologiâ. Pedagogika, 15, 3, 2015, s. 17-20.

Ings, Simon. Stalin i naukowcy. Historia geniuszu i szaleństwa. Warszawa, Wydawnictwo Agora, 2017.

Karaulov, Ûrij Nikolaevič et al., red. Russkij associativnyj slovar'. Tom 1. Moskva, Astrel', 2002.

Kot, Wiesław. Hanna Krall. Poznań, Dom Wydawniczy Rebis, 2000.

Krall, Hanna. Na wschód od Arbatu. Warszawa, Wydawnictwo Dowody na Istnienie, 2014.

Lappo, Georgij Mihajlovič, Pavel Markovič Polân. „Naukogrady Rossii: včerašnie zapretnye i poluzapretnye goroda - segodnâšnie točki rosta”. Mir Rossii, 1, 2008, s. 20-49. Web. 22.04.2020. http://elib.biblioatom.ru/text/lappo_naukogrady-rossii_2008/go,0/.

Postanovlenie GOKO № 9887ss/op ,,O Special'nom komitete pri GOKO”. Web. 23.04.2020. http:// school.rusarchives.ru/atomnyi-proekt-v-sssr/postanovlenie-goko-9887ss-o-spetsialnom-komitete-pri-goko.html.

Puzynina, Jadwiga. Język wartości. Warszawa, Wydawnictwo Naukowe PWN, 1992.

Radziecki program nuklearny. Web. 21.04.2020. https://pl.wikipedia.org/wiki/Radziecki_program_ nuklearny.

Serebrennikova, Evgeniâ Fedorovna et al. Lingvistika i aksiologiâ: ètnosemiometriâ cennostnyh smyslov: kollektivnaâ monografiâ. Moskva, Tezaurus, 2011.

Sidorova, Galina Petrovna. „Cennost' professii v sovetskoj hozâjstvennoj kul'ture i obrazah massovogo iskusstva 1960-1980-h". Čelovek i kul'tura, 1, 2013, s. 61-91. Web. 15.05.2020. https://nbpublish.com/library_read_article.php?id=291.

Szczeklik, Andrzej. „Dwie kultury”. PAUza Akademicka. Tygodnik Polskiej Akademii Umiejętności, 55, 2009. Web. 25.04.2020. http://pauza.krakow.pl/55_1_2009.pdf.

Szczygieł, Mariusz. „Wstęp. Jak Hanna Krall myliła pogoń”. Hanna Krall. Na wschód od Arbatu. Warszawa, Wydawnictwo Dowody na Istnienie, 2014, s. 5-15.

Tokarski, Ryszard. Światy za slowami. Wyktady z semantyki leksykalnej. Lublin, Wydawnictwo Uniwersytetu Marii Curie-Skłodowskiej, 2013.

Vol'f, Elena Mihajlovna. Funkcional'naâ semantika ocenki. Moskva, Nauka, 1985. 